\title{
Max Müller and the Comparative Method
}

\author{
ANGUS NICHOLLS ${ }^{1}$
}

\section{INTRODUCTION: 'THE OXFORD SOLAR MYTH'}

In 1870, a text written by the Anglo-Irish clergyman Richard Frederick Littledale appeared in Kottabos, a magazine published by Trinity College in Dublin. This article addresses a subject that in the first instance sounds both implausible and exotic namely, the existence of something referred to as 'The Oxford Solar Myth':

A very singular tradition, possibly due to the influence of classical Paganism in the course of study, still preserves, in the Oxford of the nineteenth century, the evident traces of that primeval Nature-worship whereby the earliest parents of the Aryan race marked their observance of the phenomena of the heavens [...]. The Legend takes its not infrequent shape of celebrating a great teacher, passing from his Eastern birthplace on to the West $[\ldots]$ The symbolical name by which the hero was deified, even in our own days, is Max Müller. [...]. Müller, applied in the late High German dialects to the mere grinder of corn, denotes in its root-form a pounder or crusher [...] The more scientific aspect of the question recognises here the Sun-God, armed with his hammer or battle-axe of light, pounding and crushing frost and clouds alike $[\ldots]$ We require more exact data before we can with authority allege that Max Müller is indeed the Sun, or rather the Dawn, himself. But these data are accessible and abundant. ${ }^{2}$ 
This parody of the writings of Friedrich Max Müller (1823-1900) appeared in the 1909 edition of Müller's well-known essay (actually a book length treatise) on Comparative Mythology, which was first published in 1856 and which made his name in British academia beyond the confines of Müller's narrower specialism: the philology of ancient South Asian languages, primarily Sanskrit. The fact that this parody already appeared in 1870, only fourteen years after Müller's essay on Comparative Mythology, demonstrates how quickly his theories concerning mythology and comparative philology came to attract criticism and even ridicule. ${ }^{3}$ More surprising still is the decision of Abraham Smythe Palmer, Lecturer in Divinity at Trinity College in Dublin, to reprint this parody in his 1909 edition of Müller's essay on Comparative Mythology. But the reason for this now seems relatively clear: by the early twentieth century, one needed to protect oneself with ironic gestures when publishing the works of Max Müller.

By this time Müller's essentially Kantian-cum-religious theories on the origin of language had been thoroughly eclipsed by Darwinian linguistics, and Müller began to be seen as a kind of quaint nineteenth-century sage. To cut a long and well-known story short: Müller held that language is always conceptual and that language roots emerge from a priori concepts similar to Kant's categories. By making this claim, he argued that only human beings have the capacity for conceptual thought and language, which was in turn held to constitute a decisive point of demarcation between human beings and the animal kingdom. The most primordial act of conceptual thinking was, according to Müller, to be found in ancient human attempts to conceptualize the rising sun as a symbol of the infinite (hence the 'Solar Myth' with which Müller's name became associated). During the early 1870 s, these arguments were deployed as part of 
a highly public campaign waged by Müller against Darwin's Descent of Man, a debate which has attracted a high degree of scholarly attention that will not be added to here. ${ }^{4}$ Müller's arguments of the 1870 s were an elaboration upon his earlier opposition, already announced in the first volume of his Lectures on the Science of Language in 1861, to the implications of natural selection for questions of human descent. As Müller declared in 1861:

The one great barrier between the brute and man is Language [...] Language is something more than a fold of the brain, or an angle of the skull. It admits of no cavilling, and no process of natural selection will ever distil significant words out of the notes of birds or the cries of beasts [...] language is our Rubicon and no brute will dare to pass it. ${ }^{5}$

Despite its inherent pathos for religiously inclined audiences, this argument could not withstand the barrage of data assembled by Darwinian linguists during the 1870 s and 1880 s, who argued that the mental capacity for language is already present in higher animals, and must, therefore, have evolved by natural selection. ${ }^{6}$ For this reason, Müller's period of ascendancy in Britain was a relatively brief one, lasting from the mid-1850s until the gradual acceptance of Darwinism within diachronic linguistics, a process which had already begun by the time that the Descent of Man appeared in 1871.

The focus of this paper will not be this phase of decline in Müller's academic standing, but rather that of his ascendancy between roughly 1856 (the year in which Comparative Mythology was published) and 1871, the year in which two publications that were important for Müller appeared: Darwin's Descent of Man and Edward 
Burnett Tylor's Primitive Culture. The claim to be made here is that Müller's use of the term 'comparative' in the title of his treatise on Comparative Mythology held a decisive importance within British intellectual history in the second half of the nineteenth century - an importance which, moreover, still has resonances within Anglophone comparative literature today. As George Stocking has shown in Victorian Anthropology, Müller's essay on Comparative Mythology was an influential and controversial contribution to what was known as the 'comparative method' in evolutionist anthropology (with 'evolutionism' denoting broadly pre-Darwinian notions about cultural progress rather than evolution by natural selection). This is because Müller's discipline of comparative philology was seen to have implications for debates concerning human monogenesis and polygenesis, and also those relating to cultural difference in the context of European colonial encounters with nonEuropean cultures. 'In the 1850s', writes Stocking in his authoritative study, 'Müller's inquiry had a reconstructive as well as genealogical interest', and comparative philology was seen as 'a form of prehistoric archaeology'. It was for this reason that Müller's essay on comparative mythology is said to have 'swept all of the materials of British folklore "into its orbit" for almost two decades'.

Any discussion of Müller within the context of contemporary comparative literature must be accompanied by some disclaimers. In 1850s Britain, literary studies as it is currently taught in British universities did not yet exist, with the first degree devoted to English literature - as opposed to philology - being introduced at Oxford in $1894 .^{8}$ It was philology or more specifically diachronic linguistics, and not literary studies as currently understood, that was Müller's primary research discipline, as well as being the forum for his version of the comparative method. ${ }^{9}$ Having studied under the Sanskritist Hermann Brockhaus in Leipzig, and later (between 1844 and 1846) under 
Franz Bopp in Berlin, Müller belonged to the line of comparative philologists that emerged from the initial discoveries of William Jones in his 'Third Anniversary Discourse' of $1786 .{ }^{10}$ But such linguistic study was not clearly separated from literary culture and the broader context of Romanticism - especially the German Romantic interest in India. ${ }^{11}$ As the son of the minor philhellenic poet Wilhelm Müller (17941827, otherwise known as 'Griechen-Müller'), Max Müller was literally born into this Romantic tradition, and his interest in Asian cultures may well have been aroused by his exposure to Friedrich Schlegel's Über die Sprache und Weisheit der Indier (On the Language and Wisdom of the Indians, 1808) and to Goethe's West-östlicher Divan (West-Eastern Divan, 1819). In Berlin, Müller also encountered lectures by Schelling that would later appear in Schelling's Philosophie der Mythologie (Philosophy of Mythology, 1856), and he also met with Schopenhauer in $1845 .^{12}$ Like all of these authors, Müller's image of 'the East', and more specifically of India, was heavily romanticized and bore little relation to contemporary realities; and although he was regarded as an expert on India in Victorian Britain, he never actually travelled there.

In 1846, Müller arrived in Britain in order to gain access to manuscripts of the Rigveda that were held by the East India Company in London. Müller's six-volume edition of the Vedas was only completed in 1874 , by which time he had already been established in Oxford for over twenty years, having been elected as Professor in the Taylorian Institute for Modern European Languages in $1854 .{ }^{13}$ Müller lost in the election for the prestigious Boden Chair of Sankrit in 1860, ostensibly on the grounds that he was associated with the Higher Bible Criticism of David Friedrich Strauss. The candidate who was eventually awarded this Chair - M. Monier-Williams - was apparently more inclined than Müller to see the study of Sanskrit and Indian languages along the lines of the Chair's original founder, Colonel J. Boden, who had 
opined that 'a more general and critical knowledge of the Sanskrit language' would better enable mass conversions to Christianity in British India. ${ }^{14}$

Although a specialist in Sanskrit, Müller's career at Oxford developed in the context of the Taylorian Institute. In this capacity he gave lectures on 'The Origin of the Romance Languages', on 'The History of German Civilisation and Literature, from the Earliest Times to the Reign of Charlemagne', and on 'German Literature of the Sixteenth Century', among other subjects. On this basis, according to Müller's most recent biographer, he 'established a reputation as a specialist in German literature in England'. ${ }^{15}$ This reputation was reinforced when Müller published an influential edition of German Classics in $1858,{ }^{16}$ and when he was appointed as the inaugural President of the English Goethe Society in $1886 .{ }^{17}$

From the perspective of present-day comparative literature, Müller can be seen as a rather curious research object. The comparative method to which he contributed was one that he deployed primarily in relation to ancient languages and myths, not in connection with modern literary texts. And as a more recent author on the comparative method in the history of anthropology has argued, the results achieved by this method often depended upon what one took to be its aims. Should comparisons be made in order to uncover similarities or differences between the things under investigation ${ }^{18}$ Any answer to this question must itself compare Müller's approach with that of other important thinkers in the history of comparative studies and intercultural relations. As we shall see in the following survey, in the case of the comparative method as deployed by Johann Wolfgang Goethe in relation to biological objects and later to national literatures, by Müller in relation to languages and myths, and by Müller's important evolutionist contemporaries in British intellectual history Herbert Spencer and Edward Burnett Tylor - in relation to European and non- 
European cultures, the answers to this question differed. Whereas Goethe tended to valorize difference and particularity over similarity, Müller undertook comparison in order to argue for a primordial unity between all peoples, languages and religions in the spirit of what might be called a universalist humanism and a primordial monotheism. Finally, Spencer and especially Tylor saw comparison as a method of explaining the differences between 'civilized' and 'primitive' societies in essentially pre-Darwinian evolutionist terms.

These debates were not devoid of later consequences for Anglophone literary studies and comparative literature. Goethe has rightly been seen as seminal to debates about the history of both comparative literature and so-called 'world literature' ${ }^{19}$ Moreover, the social evolutionist conception of the comparative method as it had been understood by both Spencer and Tylor found its way into an important study on Comparative Literature (1886), written by Hutcheson Macaulay Posnett, ${ }^{20}$ and as late as 1948, T. S. Eliot was still citing Tylor as the main authority on the concept of culture in English. ${ }^{21}$ Insofar as these debates are marked by issues relating to colonialism and cultural difference that are still alive in post-colonial and multi-ethnic societies like contemporary Britain, they are not merely of historical interest. Indeed, debates similar to those that took place at the origins of Anglophone comparative philology and comparative literature are still at least latently part of its contemporary existence. But in order to understand the nature of these debates in their original historical context, a brief reconstructive account of the comparative method, and of Müller's essay on Comparative Mythology, will be necessary. 
In Victorian Anthropology, George Stocking offers a useful summary of the general propositions elaborated by a number of nineteenth-century British thinkers under the moniker of the 'comparative method'. According to Stocking, these thinkers held that 'sociocultural phenomena' develop according to laws similar to those found in the natural world, with the basic developmental tendency being one of progress from simplicity to complexity. Since these thinkers assumed that all humans 'share a single psychic nature', it should be possible, they thought, to make cogent comparisons between different cultures according to their positions along a universally valid scale of human development. Differences in technology among various cultures would in these terms be explained by different rates of development, with European cultures having developed at the highest speed. According to this logic, earlier stages in European civilization would be roughly equivalent to the contemporary levels of cultural development found in some so-called 'primitive' societies. The 'comparative method' would be used in order to assess these similarities and differences. ${ }^{22}$

Stocking associates this collection of propositions with the general idea of 'social' or even 'classical' evolutionism. These evolutionist theories were conceived either prior to or concurrently with Darwin's theory of natural selection and its eventual application to humankind in the Descent of Man. Some of the key texts in this tradition included Herbert Spencer's long essay 'Progress: Its Law and Cause’ (1857), Henry Maine's The Ancient Law, Its Connection with the Early History of Society, and Its Relation to Modern Ideas (1861), John Lubbock's Pre-Historic Times, As Illustrated by Ancient Remains, and the Manners and Customs of Modern Savages (1865), and two works by Tylor: Researches into the Early History of Mankind and the Development of Civilization (1865) and Primitive Culture (1871). In order to demonstrate the Germanic roots of this tradition, it is instructive to focus here upon 
the earliest and arguably the most influential of these works: Spencer's 'Progress: Its Law and Cause'.

Spencer begins his essay by arguing that existing theories of progress are erroneously teleological in that they tend to define progress only in terms of increases in human happiness. By contrast, a more rigorous scientific approach would involve isolating laws of progress within the organic realm and seeing whether they can be applied to human societies. 'In respect to that progress which individual organisms display in the course of their evolution', writes Spencer,

this question has been answered by the Germans. The investigations of Wolff, Goethe, and Von Baer, have established the truth that the series of changes gone through during the development of a seed into a tree, or an ovum into an animal, constitute an advance from homogeneity of structure to heterogeneity of structure [...] Now, we propose in the first place to show, that this law of organic process is the law of all progress. Whether it be in the development of the Earth, in the development of Life upon its surface, in the development of Society, of Government, of Manufactures, of Commerce, of Language, of Literature, Science, Art, this same evolution of the simple into the complex, through a process of continuous differentiation, holds throughout. ${ }^{23}$

The application of biological models of development to human cultural forms, clearly on display in this passage, was part of the German tradition of philology that predates Spencer's speculations by decades. Botanical metaphors such as Stamm (stem) and Wurzel (root) can, for example, be found in the philological writings of Friedrich 
Schlegel and Franz Bopp. In 1808, Schlegel was already claiming that just as comparative anatomy had led to progress in biology, so too would comparative linguistics shed light on the phenomenon of language. ${ }^{24}$ Similarly, Bopp begins the first volume of his Vergleichende Grammatik (Comparative Grammar, 1833) by stating that languages are organisms characterized by physical and mechanical laws. ${ }^{25}$ That this tradition of German philology or Sprachwissenschaft argued that language development involves a form of progress from simplicity to complexity is demonstrated by perhaps the most prominent proponent of the biological or botanical analogy: August Schleicher, father of the Stammbaumtheorie (family tree theory) of language genealogy, who proposed that even the most highly organized of languages may originally have consisted of 'basic roots' which then coalesced to form 'composite' constructions. ${ }^{26}$ Spencer recognizes an earlier contribution to this German tradition when he argues that 'language in general exhibits advance from the homogeneous to the heterogeneous', invoking the name of Max Müller in relation to this theory of language development. ${ }^{27}$ For Spencer, the terms 'homogeneous' and 'heterogeneous' effectively came to mean 'primitive' and 'advanced' or 'civilized' when applied to human societies.

Like Spencer, Müller would also come to describe Goethe as a champion of the comparative method, citing his famous maxim 'He who knows no foreign languages does not know anything about his own' as the catchphrase of comparative philology. ${ }^{28}$ In his course of lectures on comparative philology delivered at Oxford in 1851, Müller made an explicit claim for the scientific status of philology when he stated that 'the name "Comparative Philology" shows at once the comprehensive character of the new science. In the same way as Comparative Anatomy comprises [...] the anatomy of all organic beings, Comparative Philology comprises the study [...] of all 
languages spoken by man'. ${ }^{29}$ In this Müller was hardly an innovator. Müller's novelty within the British context was to make these theories accessible to a learned British public by writing about them in English and by presenting public lectures that argued for the importance of philology in being able to answer key questions about human history. It was in this context that Müller also made his speculative claim for an underlying similarity between all human cultures, a claim that purportedly related to the human ability to conceptualize the infinite in language. For Müller, then, the main goal of comparison was to unveil a primordial unity that lay beneath all apparent diversity. In this he actually stood in opposition to another post-Kantian German theorist of comparison: Johann Wolfgang Goethe.

\section{GOETHE AND MÜLLER ON COMPARISON}

It may be possible to claim that processes of comparison can themselves be compared according to two essential methodological categories: the first being a method which, beginning with empirical observations, goes on to construct heuristic ideal types which may later be revised or adjusted depending on subsequent experience; the second assuming a priori an ideal commonality that is later seen to be confirmed through empirical observations. The first method is generally inductive; the second is deductive. In practice, most processes of comparison will use a combination of these methods, both of which would be subject to particular shortcomings when left in isolation: the weakness of the first method may be a lack of any consistent guiding model or hypothesis through which empirical observations could be ordered; while the weakness of the second method may be that the assumed commonality or identity will tend to influence, in advance, the selection of materials and the observations 
made. The first model would tend to emphasize difference and particularity, whereas the second would stress similarity or even universality. In the following analysis it will be shown that Goethe's approach can be situated more within the first category and Müller's within the second.

During the 1790s, Goethe attempted to develop theoretical models that would help him to compare different botanical and zoological species with one another. These attempts were made under the influence of Kant's third Critique, the Kritik der Urteilskraft (Critique of Judgement), which Goethe read more or less immediately upon its publication in $1790 .^{30}$ The problem of comparison was for Goethe a Kantian problem, in that he felt that any process of anatomical comparison would need, at the outset, to develop a heuristic model or archetype against which individual organisms could be compared. We already see a naive version of this purely theoretical or formal notion of type in Goethe's notion of the primal plant or Urpflanze, developed in the late $1780 \mathrm{~s},{ }^{31}$ which Schiller would later (in 1794) famously declare to be not an object of experience but something more akin to Kant's notion of an idea of pure reason. ${ }^{32}$

This notion of an organizing archetype appears again in Goethe's essays on comparative anatomy written in 1795-96. There we are told that comparative anatomy requires us to develop a universal archetype of animal development that will be abstracted from empirical observations of different organisms: 'Empirical observation must first teach us what parts are common to all animals, and how these parts differ. The idea must govern the whole, it must abstract the general picture in a genetic way. Once such an archetype is established, even if only provisionally, we may test it quite adequately by applying the customary methods of comparison. ${ }^{33}$ Here Goethe insists that the archetype is nothing more than a provisional synthesis of separate empirical observations. It cannot be established purely a priori, but may be used heuristically, 
roughly in the manner suggested by Kant in the third Critique, in order to guide further inquiries. In being nothing more than an abstraction derived from empirical observation, the archetype is open to testing and revision in light of further empirical experience. Individual species might then be ordered according to the extent to which they either conform to or depart from such an ideal type.

Goethe returns to these questions some two decades later, in a more explicitly literary context, in the introductory 'Notes and Disquisitions' to the West-Eastern Divan (Noten und Abhandlungen zum West-östlichen Divan). ${ }^{34}$ Drawing a specific analogy with biological comparison or Naturkunde, he discusses the possibility of identifying what he calls 'natural forms of poetry' (Naturformen der Poesie) which would have universal or transcultural validity. 'Along this path' according to Goethe, 'one can achieve a fine perspective upon the poetic varieties as well as on the characters of nations. ${ }^{35}$ This discussion of natural poetic types occurs within the context of intercultural comparisons undertaken not only by Goethe in the Divan but also by William Jones in his 'Essay on the Poetry of Eastern Nations' of $1772 .^{36}$

In his notes for the Divan, Goethe criticizes Jones for comparing the poetic productions of the Middle East too closely with European models, alleging that such comparisons may prevent the reader from seeing the Middle Eastern texts within their own cultural contexts. For Goethe, comparisons can only operate within certain limits that are revealed by the researcher's level of reflexivity. In this connection he observes that 'everyone makes judgement easier for himself through comparison, but one also makes it more difficult: because when an analogy, in being pushed too far, is halted, so too will a comparative judgment become always more unfitting, the more closely one observes it' ${ }^{37}$ Of note here is the merely provisional status that Goethe affords to such comparative archetypes. As a keen reader of Kant, Goethe is aware 
that such models are merely the constructions of our reason rather than models that are likely to coincide with empirical reality in itself. It is for precisely for this reason that they need to be tested against empirical reality.

It was this Kantian awareness that made Goethe into a thinker who emphasized particularity and difference over and above commonality and unity. Goethe recognizes that archetypes, theories and general models are indispensable for processes of comparison, but he also continually emphasizes the right of nature, or in this case of literary texts, to differ from these models. Nevertheless, this did not prevent Goethe from lapsing into a classical Eurocentrism when it came to proposing his purportedly universal categories of literary classification. 'There are', he writes, 'only three authentic natural forms of poetry: the clearly narrating, the enthusiastically inspired, and the personally plot-oriented: Epos, Lyric and Drama.' ${ }^{38}$ Peter Szondi has shown the extent to which these categories were inspired by Goethe's reading of Aristotle's Poetics, ${ }^{39}$ suggesting that any purportedly transcultural or universal categories of cultural analysis will always be conceived within a particular cultural context - in this case, Greek classicism - that would limit their objectivity.

How does this approach compare with that of Max Müller in the essay on Comparative Mythology? The answer to this question is a straightforward one: whereas Goethe, despite his eventual Eurocentrism, is interested in difference and particularity, Müller wishes to demonstrate an underlying commonality among myths that he sees as belonging to the so-called 'Aryan' or Indo-Germanic languages. This underlying unity is said by Müller to have existed in what he calls the 'mythological age'. It is this mythological age that is the primary object of Müller's essay on Comparative Mythology: 
Comparative philology has since brought this whole period within the pale of documentary history. It has placed in our hands a telescope of such power that, where formerly we could see but nebulous clouds, we now discover distinct forms and outlines; nay, it has given us what we may call contemporary evidence, exhibiting to us the state of thought, language, religion and civilisation at a period when Sanskrit was not yet Sanskrit, Greek not yet Greek, but when both, together with Latin, German and other Aryan dialects, existed as yet as one undivided language. $^{40}$

At the level of rhetoric, this passage demonstrates the way in which Müller tended to use natural scientific metaphors in order to establish the prestige of comparative philology. This new discipline will, he argues, provide us with a telescope through which we can gaze into ancient history. It will also allow us to resolve, once and for all, a philosophical problem that had confronted Western philosophers at least since Socrates's critiques of myth in Plato's dialogues. Namely, what is the function of myths and why do myths appear to be so irrational?

Müller's well-known answer is that myth is a 'disease of language'. ${ }^{41}$ He speculates that early 'Aryan' dialects were characterized by a series of general and abstract substantives - such as 'day', 'night', 'sky', 'earth' or 'thunder' - that did not refer to particular objects but rather to general potentialities or forces which were seen to act upon the world, even if no definite subject could be identified as generating these forces. Since in ancient Greek and Sanskrit these general and abstract substantives were assigned genders, 'it was simply impossible to speak of morning or evening, of spring and winter, without giving to these conceptions something of an individual, active, sexual and at last personal character'. ${ }^{42}$ Myth therefore emerges from 'that 
particular difficulty which the human mind experiences in speaking of collective or abstract ideas'. ${ }^{43}$ And once these natural forces had been assigned genders and personalities, it was inevitable, in Müller's view, that this would lead to elaborate narratives involving male and female gods. The classical example used by Müller to make this argument is the Hindu god Dyaus, who is associated with the sky and sun, and is said to 'light the sky'. Linguistically the term Dyaus is said by Müller to underlie the Indo-European derivations of deva, deus and deity. ${ }^{44}$ All three terms emerged, in Müller's view, from the Sanskrit root $d i v$ or $d y u$ : to shine or brighten. In this way, Dyaus is said to be the Sanskrit version of the god that was known in Europe as Zeus and Jupiter. ${ }^{45}$ It is this web of speculative philological arguments - all of which are aimed at demonstrating an underlying similarity between the Sanskrit and ancient Greek cultures - that led to the 'Solar Myth' pilloried by Littledale in the quotation that begins this article.

For Müller, the evidence provided by ancient Greek and Sanskrit literature leads back to the primordial moment at which the ancient 'Aryans' first attempted to describe the dawn. What was initially a simple description of a natural phenomenon is said to have degenerated over time into a series of elaborate narratives involving gods and goddesses. In this way Müller is able to present himself as the scholar-detective: digging beneath the surface of these myths in order to find the ancient language roots that underlie them. Myths that seem, on the surface, to be different, are thereby said to have emerged from a single common source. But Müller's common source is not merely a hypothetical model as in the case of Goethe. For Müller it is much more a buried historical fact that can purportedly be deduced from the grammatical similarities between Sanskrit and ancient Greek. In other words, Müller's conception of comparative method seeks to find a primordial unity that underlies diversity. In this 
he demonstrates both the pitfalls and the potential benefits of a comparative method that emphasizes similarity over difference.

\section{MÜLLER'S CONTEMPORARY RELEVANCE, OR: A 'NEGATIVE} DIALECTICS' OF COMPARISON

The question as to whether Müller's ideas on the comparative method are in any way relevant to the discipline of comparative literature today must be preceded by some observations on historical context. The first point to make is that Müller was a philologist and not a literary scholar in our modern sense of that term. His main task, within the context of the Taylorian Institution, was the teaching of diachronic linguistics and not the interpretation of literary texts. Second, Müller's arguments concerning the underlying unity of a primordial 'Aryan' language were couched within the more speculative idea that all languages might have emerged from a single common source. Such arguments were in part made in order to oppose the theory of human polygenesis - the notion that there are different species of human beings with entirely separate biological origins. This idea was not entirely killed off until well after the Origin of Species and the Descent of Man had been published. ${ }^{46}$

Yet even when these contexts are taken into account, Müller's desire to find an underlying unity beneath diversity would seem to be completely at odds with the contemporary concerns of comparative literature. Whereas contemporary comparative literature might tend to celebrate difference, particularity, cultural specificity and (most recently) untranslatability as a means of critiquing so called 'world literature', ${ }^{47}$ Müller's approach was characterized by a Christian humanism that had some at least questionable political consequences. Here Müller's ideas about India are a case in 
point. In many ways Müller was - at least within the context of his age - tolerant and progressive in relation to British policy in India. He advised missionaries to find points of commonality between the Hindu and Christian traditions, rather than urging complete conversion from the former to the latter. 'By unduly depreciating all other religions', he wrote in 1870, 'we have placed our own in a position which its founder never intended for it; we have torn it away from the sacred context of the history of the world. ${ }^{48}$ Expanding upon these ideas in a controversial lecture delivered at Westminster Abbey in 1873, Müller even speculated that a new religion might be created out of both traditions. 'Whenever two religions', he argued,

are brought into contact, when members of each live together in peace, abstaining from all direct attempts at conversion [...] it calls out the best elements in each, and at the same time keeps under all that is of doubtful value, of uncertain truth. Whenever this has happened in the history of the world, it has generally led to the reform of both systems, or to the foundation of a new religion. ${ }^{49}$

Although progressive for their time, these ideas were framed by the notion that the ancient Vedas were in fact monotheistic in orientation, and that Hinduism and Christianity had emerged from a single and primordial religion based upon worship of the sun. Within this context, Hindu polytheism was seen as a degenerated form of a primordial and monotheistic Hinduism. ${ }^{50}$ Many in India perceived this to be a heavily biased Christian take on the Hindu tradition, and this is perhaps why one Indian biography of Max Müller carries a very polemical title indeed. ${ }^{51}$ 
Müller's desire, expressed through his use of the comparative method, to find similarity and unity between the East and the West led him to appropriate the otherness of India to his own Christian cultural context. This won him both friends and enemies in India, where his name still adorns all Goethe Institutes, known as Max Müller Bhavans. Further to this, and as Léon Poliakov has convincingly argued, ${ }^{52}$ Müller's speculations about an ancient 'Aryan' language that later branched off into Sanskrit and ancient Greek provided fuel for later attempts to draw links between language and race, even if Müller himself discouraged the making of such connections when he observed that 'it is unscientific [...] to speak of an Aryan race, of Aryan blood or of Aryan skulls and then to attempt to make ethnological classifications upon linguistic foundations'. ${ }^{53}$

The potential value of Müller, and perhaps one of the reasons why he has come to be seen - at least in some quarters - as a beacon of intercultural understanding within the context of Western encounters with India, is the extent to which he offered an appealing counter-model to mainstream social evolutionism as found in thinkers such as Spencer and Tylor. In this context, a comparative method that emphasized universality and similarity over difference had the effect of implicitly opposing the dominant paradigm of social evolutionism and its notion that culture 'progresses' in stages from simplicity to complexity and from 'primitive' to 'civilized' - a paradigm that saw the cultures of northern Europe as representing the highest possible point along the scale of cultural development. George Stocking has underlined the political significance of Müller's thesis concerning a commonality between the ancient Greek and Sanskrit traditions - a notion which, following the so-called 'Indian Mutiny' of 1858, suggested that 'one blood flowed' in the veins of British soldiers and the Indian 'mutineers' whom they sought to suppress. ${ }^{54}$ And despite the fact that Müller's 
version of the comparative method came to be associated with social evolutionism, Müller's thesis that myth is a 'disease of language' also implied that human societies are subject not only to progress but also to degeneration, or a kind of falling off from a pure and primordial scene of revelation that is universal to all humanity. If the ability to conceive of the infinite in language can already be found in the "Solar Mythology' belonging to Müller's 'mythological age', then even the earliest human societies had the ability to form sophisticated and abstract concepts in language.

This deeply religious idea, which also fed into Müller's critique of Darwin, placed Müller on a direct collision course with the social evolutionist mainstream of Victorian thought, represented by Spencer and especially by Tylor. While Müller found in the Vedas evidence of a primal monotheism which had allegedly 'degenerated' into polytheistic mythology through the 'disease of language', Tylor held the opposite view: namely, that monotheism is an evolved form of the animistic polytheism that colonial ethnographers had found in the myths of various 'primitive' cultures. These two schools of thought - the first often called the 'etymological school' and associated with Müller and later with the German theologian Wilhelm Schmidt; ${ }^{55}$ the second the anthropological school, linked with Spencer and Tylor, with the anthropologist and historian Andrew Lang, and later with James George Frazer, author of the Golden Bough - were engaged in public debate during the closing stages of the nineteenth century. ${ }^{56}$ The main issue at stake in this debate was the nature of human progress.

As we have seen, Spencer maintains that human progress, like all forms of progress in his view, moves from a state of homogeneity and simplicity to one of heterogeneity and complexity. According to this model, 'primitive' or homogeneous levels of development can still be observed among 'existing barbarous tribes', while 
heterogeneity or civilization can be seen in its most advanced state in European culture. ${ }^{57} \mathrm{~A}$ similar view is taken by Tylor in Primitive Culture, where we are informed that 'the educated world of Europe and America practically settles a standard by simply placing its nations at one end of the social series and savage tribes at the other, arranging the rest of mankind between these limits [...] as they correspond more closely to savage or to cultured life' ${ }^{58}$ These essentially colonialist and racist ideas - often informed by the 'fieldwork' of amateur ethnographers in colonial outposts who had been primed in advance by evolutionist theory ${ }^{59}$ - directly influenced Anglophone literary studies, most obviously in Frazer's Golden Bough and its subsequent reception by T. S. Eliot, ${ }^{60}$ but also in Hutcheson Macaulay Posnett's important monograph on Comparative Literature $(1886) .^{61}$

For Posnett, various forms of literature emerge from 'social and mental evolution', which belongs to the general 'movement of civilization'. ${ }^{62}$ Comparison, which is the 'primary scaffolding' of human thought, allows us to see the emergence of these literary forms, and it was the 'discovery of the New World' which 'awakened men' to contrasts in the different stages of civilization. ${ }^{63}$ Posnett's approach to comparative literature was a polemical response to Arnoldian notions about literary value, which he saw as inherently speculative and unscientific. Publishing his study on Comparative Literature within Kegan Paul's International Scientific Series - which also included works by Spencer, by the Darwinian linguist William Dwight Whitney, and by perhaps Darwin's staunchest champion in Britain, Thomas Henry Huxley Posnett was aiming to establish comparative literature as a discipline within the social sciences.

'Literature', according to Posnett, 'far from enshrining universal forms and ideas of beauty, owes both its creative and critical works to the development of social life. ${ }^{64}$ 
Drawing upon the social evolutionism of Henry Maine, Posnett sees literary development as mirroring the progression from clan societies to modern nation states, in which the life of the individual comes to be seen as more important than that of the group. It is such conditions that enable what Posnett calls the "principle of literary growth'; namely: 'the progressive deepening and widening of personality'. ${ }^{65}$

Such a view of comparative literature was of course inclined to see European letters as existing at the advanced end upon the scale of literary evolution. This is why, to cite just one example, Posnett sees 'the castes and village communities of India' and the 'family system and sentiments of China' as having 'prevented the growth of that individualised life which has become in Europe the main source of literary as well as of scientific ideas' ${ }^{66}$ Such claims were made without any reading knowledge of the languages in question - Posnett in fact admits to having used Müller's translation of the $\operatorname{Vedas}^{67}$ - and on the basis that literary texts can be reduced to the sociological conditions that purportedly underlie them.

Against this backdrop, the humanist and philological character of Müller's emphasis upon similarity and underlying unity is revealed. Whereas Spencer, Tylor and Posnett deploy the comparative method in order to reveal differences marked out upon an evolutionary continuum that leads onwards and upwards into the purportedly liberating light of European civilization, Müller carries out linguistic comparisons in order to reconstruct an (admittedly speculative) primordial unity at the very origins of humankind, origins that are located at the intersection between West and East, between ancient Greek and Sanskrit. And whereas the British thinkers took from Goethe the idea that comparison enables one to see progressive development along an evolutionary scale, Müller emphasizes Goethe's genuine interest in non-European cultures and languages, even if - particularly in Müller's case - such an interest 
tended to see these cultures (especially Hinduism) is specious monotheistic and Christian terms. In the Preface to the 2003 edition of Orientalism, Edward Said invokes precisely this 'humanist' tradition of German philology as the main line of inheritance to which he sees himself as belonging as a comparatist. ${ }^{68}$ And if, as one of the recent American Comparative Literature Association 'State of the Discipline' reports has suggested, contemporary comparative literature in the West has been shaped not only by the legacies of European colonialism, but also by the co-existence of Western and non-Western cultures within modern societies, ${ }^{69}$ then the two competing historical versions of the comparative method discussed in this paper comparison in order to identify difference and comparison in search of similarity - are not of mere antiquarian interest. Indeed, the questions that they raise concerning civilization, progress and the relations between the religions and cultures of the West and the East continue to stand at the very centre of our discipline today.

The opposition between inductive (empirical) and deductive (a priori) modes of comparison is one so basic to thought that it cannot be overcome or 'sublated'. In contemporary debates about culture within multicultural Western societies, it seems that both must be held in tension with one another. This would amount to a "negative dialectics' of cultural comparison in which neither of the two positions can be regarded as foundational. ${ }^{70}$ One the one hand, cultural specificity and particularly the value attached to individual languages and traditions, along with the need to grant special rights in order to accommodate some cultural groups, should not be relinquished in the name of a Eurocentric conception of enlightenment humanism. ${ }^{71}$ Yet on the other hand, some conception of universal human rights, and some at least implicit notion of an overall human project that involves progress, are seemingly essential to any society, and in the West, such conceptions usually emerge from 
European sources. This tension is most obviously apparent in Western debates concerning the extent to which the religious practices of some non-European immigrants may infringe upon individual human rights, especially those of women. ${ }^{72}$

It is clear that Müller - in arguing for a primordial unity at the 'dawn' of culture situated himself on the universalist and a priori end of this spectrum, and in this he demonstrates both the advantages and the pitfalls of universalism. The assertion of a primordial unity at the origins of humanity brings with it an essential humanism according to which all traditions are afforded a basic measure of respect. But it also carries the risk of projecting one's own cultural prejudices and preoccupations onto the purported origin. In Müller's case, this involved positing a primordial monotheism at the beginnings of Hinduism, a claim which led him to misread the Hindu tradition and which garnered him enemies in the Indian subcontinent. For our discipline, Müller is instructive in the following sense: the urge to translate, to understand, to decode, and to find similarity is indispensable to cultural comparison. But this urge must be tempered by high levels of reflexivity of the kind that Goethe recommended if it is not to collapse into Eurocentric projection and cultural hegemony. The 'world' is always seen from one's own perspective, and so any conception of a universal 'human' culture, or for that matter of 'world' literature, ${ }^{73}$ must be accompanied by an awareness of the inherent risks of universalism.

${ }^{1}$ I would like to thank the organizers and attendees of the Oxford Comparative Criticism conference on Comparative Criticism: Histories and Methods, 25-26 September 2013, for their comments on an earlier version of this paper. Aspects of the research presented here also appear in different contexts in the following articles: Angus Nicholls, 'A Germanic Reception in England: Friedrich Max Müller's Critique of Darwin's Descent of Man', in The Literary and Cultural Reception of Charles Darwin in Europe, edited by 
Thomas F. Glick and Elinor Shaffer (London: Bloomsbury, 2014), pp. 68-90; Angus Nicholls, 'Between Natural and Human Science: Scientific Method in Goethe's Noten und Abhandlungen zum West-östlichen Divan', Publications of the English Goethe Society, 80.1 (2011), 1-18.

${ }^{2}$ R. F. Littledale, 'The Oxford Solar Myth,' originally appearing anonymously in Kottabos, 5 (1870), 145-154; reprinted with the author's name in Echoes from Kottabos, edited by R. Y. Tyrrell and Edward Sullivan (London: E. Grant Richards, 1906), pp. 279290, and in Max Müller, Comparative Mythology: An Essay, edited by A. Smythe Palmer (London: George Routledge and Sons, 1909), pp. xxxi-xlvii. Müller's essay on Comparative Mythology first appeared as Part 1 of the Oxford Essays published in 1856. Smythe Palmer's 1909 edition, easily available online, is cited throughout this essay.

${ }^{3}$ Littledale was the brother-in-law of William Wright, an Orientalist who came to regard Müller as having compromised his academic integrity in his attempts to further the public cause of comparative philology. For background see Bernhard Maier, 'Habent sua fata libelli: Thoughts on an Early Parody of Max Müller and Other Classics in Comparative Religious Studies', Religion, 42.4 (2012), 495-519.

${ }^{4}$ This campaign was waged most directly by Müller in his three 'Lectures on Mr. Darwin's Philosophy of Language', published in separate issues of Fraser's Magazine in 1873 (May, 525-541; June, 659-679; July, 1-24), but it also continued more or less until the end of his career. See Linda Dowling, 'Victorian Oxford and the Science of Language', PMLA, 97 (1982), 160-178; Gregory Schrempp, 'The Re-Education of Friedrich Max Müller: Intellectual Appropriation and Epistemological Antinomy in MidVictorian Evolutionary Thought', Man, 18 (1983), 90-110; Elizabeth Knoll, 'The Science of Language and the Evolution of Mind: Max Müller's Quarrel with Darwinism', Journal of the History of the Behavioural Sciences, 22 (1986), 3-22; Robert 
J. Richards, Darwin and the Emergence of Evolutionary Theories of Mind and Behavior (Chicago: University of Chicago Press, 1987), pp. 200-206; Lourens P. van den Bosch, 'Language as the Barrier between Brute and Man: Friedrich Max Müller and the Darwinian Debate on Language', Saeculum, 15 (2000), 57-89; Nicholls, 'A Germanic Reception in England', pp. 68-90.

${ }^{5}$ Friedrich Max Müller, Lectures on the Science of Language, First Series (London: Longmans, Green and Co., 1861), p. 340.

${ }^{6}$ See, for example, George John Romanes, Mental Evolution in Animals (London: Kegan, Paul, Trench and Co., 1883).

${ }^{7}$ Stocking, Victorian Anthropology (New York: The Free Press, 1987), pp. 59, 61; the second quote includes Stocking citing the view of Richard M. Dorson in The British Folklorists: A History (Chicago: University of Chicago Press, 1968), p. 66.

${ }^{8}$ See Aladár Sarbu, 'English as an Academic Discipline: Some History', Neohelicon, 32. 2 (2005), 443-456 (p. 452).

${ }^{9}$ The biographical information summarized here is indebted to the account provided by Lourens P. van den Bosch in Friedrich Max Müller: A Life Devoted to the Humanities (Leiden: Brill, 2002), see the opening 'Biographical Essay' on pp. 1-183.

${ }^{10}$ See William Jones, 'Third Anniversary Discourse, on the Hindus, delivered to the Asiatic Society, 2 February 1786', in Selected Poetical and Prose Works, edited by Michael J. Franklin (Cardiff: University of Wales Press, 1995), pp. 355-367. For an overview of this notion of the comparative method in linguistics, see Henry M. Hoenigswald, 'On the History of the Comparative Method', Anthropological Linguistics, 35.1/4 (1993), 54-65.

${ }^{11}$ For general context, see: A. Leslie Wilson, A Mythical Image: The Idea of India in German Romanticism (Durham, NC: Duke University Press, 1964); Dorothy M. 
Figueira, The Exotic: A Decadent Quest (Albany, NY: State University of New York Press, 1994); Susanne Marchand, German Orientalism in the Age of Empire (Cambridge: Cambridge University Press, 2009).

${ }^{12}$ Bosch, Friedrich Max Müller, pp. 5, 22-23, 27, 29.

${ }^{13}$ Bosch, Friedrich Max Müller, pp. 34-35, 50.

${ }^{14}$ Quoted in Bosch, Friedrich Max Müller, pp. 80-81.

${ }^{15}$ Bosch, Friedrich Max Müller, p. 61.

16 Friedrich Max Müller, ed., German Classics, From the Fourth to the Nineteenth Century (London: Longmans, 1858).

${ }^{17}$ See the correspondence relating to this appointment in The Life and Letters of the Right Honourable Friedrich Max Müller, 2 vols (London: Longmans, Green and Co., 1902), II, 195-196 (p. 202).

18 Andre Beteille, 'Some Observations on the Comparative Method', Economic and Poltical Weekly, 24.4 (1990), 2255-2263 (p. 2257).

${ }^{19}$ See, for example, Hendrik Birus, 'The Goethean Concept of World Literature and Comparative Literature', in Comparative Literature and Comparative Cultural Studies, edited by Steven Tötösy de Zepetnek (West Lafayette, IN: Purdue University Press 2003), pp. 11-22; see also David Damrosch's discussion of Goethe in What is World Literature? (Princeton, NJ: Princeton University Press, 2003), pp. 1-36.

${ }^{20}$ Hutcheson Macaulay Posnett, Comparative Literature (London: Kegan Paul, Trench and Co., 1886), pp. 18-19.

${ }^{21}$ T. S. Eliot, Notes Towards the Definition of Culture (London: Faber and Faber, 1948), p. 22 .

${ }^{22}$ Stocking, Victorian Anthropology, p. 170. 
${ }^{23}$ Herbert Spencer, 'Progress: Its Law and Cause', Westminster Review, 67 (1857), 445485.

${ }^{24}$ Friedrich Schlegel, Über die Sprache und Weisheit der Indier (Heidelberg: Mohr und Zimmer, 1808), p. 137; quoted in Andreas Gardt, Geschichte der Sprachwissenschaft in Deutschland vom Mittelalter bis ins 20. Jahrhundert (Berlin: Walter De Gruyter, 1999), p. 271.

25 Franz Bopp, Vergleichende Grammatik des Sanskrit, Zend, Griechischen, Lateinischen, Litthauischen, Gothischen und Deutschen, 3 vols (Berlin: Dümmler, 1833), vol. I, p. iii.

${ }^{26}$ August Schleicher, Die Deutsche Sprache (Stuttgart: Cotta, 1860), p. 33.

${ }^{27}$ Spencer, 'Progress: Its Law and Cause', p. 457.

28 Friedrich Max Müller, Introduction to the Science of Religion: Four Lectures Delivered at the Royal Institution in February and March 1870 (London: Spottiswoode and Co., 1870), pp. 4-5. Goethe's remark in the original German is: 'Wer fremde Sprachen nicht kennt, weiß nichts von seiner eigenen', from Maximen und Reflexionen, in Johann Wolfgang von Goethe, Sämtliche Werke nach Epochen seines Schaffens (Münchner Ausgabe), edited by Karl von Karl Richter, Herbert G. Göpfert, Norbert Miller and Gerhard Sauder, 21 vols in 31 (Munich: Hanser, 1985-1998), vol. XVII, p. 737. The Münchner Ausgabe will hereafter be cited as MA followed by volume, volume part (where relevant) and page numbers.

${ }^{29}$ Friedrich Max Müller, First Course of Lectures on Comparative Philology at Oxford 1851, archives, Bodleian Library, MS Eng. d. 2353, quoted in Bosch, Friedrich Max Müller, p. 51.

${ }^{30}$ See Robert J. Richards, The Romantic Conception of Life: Science and Philosophy in the Age of Goethe (Chicago: University of Chicago Press, 2002), pp. 427-430. 
${ }^{31}$ See Goethe to Herder, 17 May 1787, in Sämtliche Werke. Briefe, Tagebücher und Gespräche, edited by Hendrik Birus, Dieter Borchmeyer, Karl Eibl, Wilhelm Voßkamp et al., 40 vols, (Frankfurt a.M.: Deutscher Klassiker Verlag, 1985-2003), part 1, XV/1, 346. Hereafter cited as FA followed by part, volume and page numbers.

${ }^{32}$ See Goethe's account of his 1794 discussion with Schiller concerning the Urpflanze in FA part 1, XXIV, 434-438.

33 'Die Erfahrung muß uns vorerst die Teile lehren, die allen Tieren gemein sind, und worin diese Teile verschieden sind. Die Idee muß über dem Ganzen walten und auf eine genetische Weise das allgemeine Bild abziehen. Ist ein solcher Typus auch nur zum Versuch aufgestellt, so können wir die bisher gebräuchlichen Vergleichungsarten zur Prüfung desselben sehr wohl benutzen.' Goethe, 'Erster Entwurf einer allgemeinen Einleitung in die vergleichende Anatomie, ausgehend von der Osteologie', in FA, part 1, XXIV, 227-266 (p. 230). 'First Outline for a General Introduction to Comparative Anatomy, Commencing with Osteology', (1795-96), in Scientific Studies, edited and translated by Douglas Miller (New York: Suhrkamp, 1988), pp. 117-126 (p. 118).

${ }^{34}$ See Nicholls, 'Between Natural and Human Science'.

35 ‘Auf diesem Wege gelangt man zu schönen Ansichten sowohl der Dichtarten als des Charakters der Nationen.' Goethe, MA, XI, part 1/2, 195.

${ }^{36}$ See William Jones, 'Essay on the Poetry of the Eastern Nations (1772)', in Selected Poetical and Prose Works, pp. 319-335.

37 'Jedermann erleichtert sich durch Vergleichung das Urtheil, aber man erschwert sich's auch: denn wenn ein Gleichniß, zu weit durchgeführt, hinkt, so wird ein vergleichendes Urtheil immer unpassender, je genauer man es betrachtet.' Goethe, MA, XI, part 1/2, 188.

38 'Es giebt nur drey ächte Naturformen der Poesie: die klar erzählende, die 
enthusiastisch aufgeregte und die persönlich handelnde: Epos, Lyrik und Drama.' Goethe, MA, XI, part 1/2, 194.

39 See Peter Szondi, Poetik und Geschichtsphilosophie II. Von der normativen zur spekulativen Gattungspoetik, edited by Wolfgang Fietkau (Frankfurt a.M.: Suhrkamp, 1974), pp. 76-77.

${ }^{40}$ Müller, Comparative Mythology, p. 21.

${ }^{41}$ See Bosch's discussion of the various texts in which Müller makes this claim in Bosch, Friedrich Max Müller, pp. 260-266.

${ }^{42}$ Müller, Comparative Mythology, pp. 72-73.

${ }^{43}$ Müller, Comparative Mythology, p. 78.

${ }^{44}$ Müller, Introduction to the Science of Religion: Four Lectures Delivered at the Royal Institution in February and March 1870 (London: Spottiswoode and Co., 1870), pp. 5860.

${ }^{45}$ Müller, Lectures on the Origin and Growth of Religion (London: Longmans, Green and Co., 1878), pp. 276-278.

${ }^{46}$ See Stocking, Victorian Anthropology, pp. 62-69; 148-149; 182-185.

47 See Emily Apter, Against World Literature: On the Politics of Untranslatability (London: Verso, 2013).

${ }^{48}$ Müller, Introduction to the Science of Religion, p. 50.

49 See Müller, 'Westminster Lecture, On Missions' (1873), in Chips from a German Workshop, 4 vols (London: Longmans, Green and Co., 1867-1875), IV, 251-290 (pp. 268-269).

${ }^{50}$ See Müller's denigration of contemporary Hinduism in his 'Westminster Lecture, On Missions', pp. 263-264; See also the discussion in Bosch, Friedrich Max Müller, p. 363. 
${ }^{51}$ Brahm Datt Bharti, Max Müller, A Lifelong Masquerade: The Inside Story of a Secular Christian Missionary who Masqueraded all his Lifetime from Behind the Mask of Literature and Philology and Mortgaged his Pen, Intellect and Scholarship to Wreck Hinduism (New Delhi: Era Books, 1992).

${ }^{52}$ Léon Poliakov, The Aryan Myth: A History of Racist and Nationalist Ideas in Europe (London: Chatto and Heinemann, 1974), p. 214.

53 'es ist unwissenschaftlich [...] von Arischer Race, von Arischem Blut, oder von Arischen Schädeln zu sprechen, und dann ethnologische Classificationen auf linguistischen Grundlagen zu versuchen.' Müller, Über die Resultate der Sprachwissenschaft; Vorlesung gehalten in der kaiserlichen Universität zu Strassburg am 23. Mai 1872 (Strasbourg: Trübner, 1872), p. 17.

${ }^{54}$ Stocking, Victorian Anthropology, p. 68.

${ }^{55}$ See Wilhelm Schmidt, Der Ursprung der Gottesidee: Eine historisch-kritische und positive Studie, 12 vols (Münster: Aschendorffsche Verlagsbuchhandlung, 1912-1955).

${ }^{56}$ In his Christianity and Mythology (1900), the journalist John Mackinnon Robertson refers to the 'etymological' school of Müller, and the 'anthropological' school associated with Spencer, Tylor, Lang and Frazer. See J. M. Robertson, Christianity and Mythology (London: Watts, 1900), pp. 19-28. For a more recent discussion of this clash of epistemologies see Stocking, Victorian Anthropology, pp. 305-309.

${ }^{57}$ Spencer, 'Progress: Its Law and Cause', pp. 452-453.

${ }^{58}$ Edward Burnett Tylor, Primitive Culture, 2 vols (London: John Murray, 1871), I, 23.

${ }^{59}$ See for example, the account of the Australian ethnographers Baldwin Spencer and F. J. Gillen in Angus Nicholls, 'Anglo-German Mythologics: The Australian Aborigines and Modern Theories of Myth in the Work of Baldwin Spencer and Carl Strehlow', History of the Human Sciences, 20.1 (2007), 83-114. 
${ }^{60}$ See Marc Manganaro, Myth, Rhetoric and the Voice of Authority: A Critique of Frazer, Eliot, Frye and Campbell (New Haven, CT: Yale University Press, 1992).

${ }^{61}$ For context on Posnett, see Simon During, 'Comparative Literature', English Literary History, 71.2 (2004), 313-322.

${ }^{62}$ Hutcheson Macaulay Posnett, Comparative Literature (London: Kegan, Paul, Trench and Co., 1886), pp. 19, 70.

${ }^{63}$ Posnett, Comparative Literature, pp. 73, 75.

${ }^{64}$ Posnett, Comparative Literature, p. 8.

${ }^{65}$ Posnett, Comparative Literature, p. 62 (on Maine), p. 72.

${ }^{66}$ Posnett, Comparative Literature, p. 335.

${ }^{67}$ Posnett, Comparative Literature, p. 289.

${ }^{68}$ Edward Said, Orientalism (London: Penguin, 2003), p. xviii. [First published 1978.]

${ }^{69}$ Charles Bernheimer, ed., Comparative Literature in the Age of Multiculturalism (Baltimore: Johns Hopkins University Press, 1995).

${ }^{70}$ Theodor W. Adorno, Negative Dialektik (Frankfurt a.M.: Suhrkamp, 1966).

71 Will Kymlicka, Multicultural Citizenship: A Liberal Theory of Minority Rights (Oxford: Oxford University Press, 1995).

${ }^{72}$ See, for example, Susan Moller Okin, Is Multiculturalism Bad for Women? edited by Joshua Cohen, Michael Howard and Martha C. Nussbaum (Princeton, NJ: Princeton University Press, 1999).

${ }^{73}$ See Charles Forsdick, 'Worlds in Collision: The Languages and Locations of World Literature', in A Companion to Comparative Literature, edited by Ali Behhad and Dominic Thomas (Malden, MA: Blackwell, 2014), pp. 473-489. 
